\title{
Unification of the German Red Cross and of the Yemen Red Crescent Society
}

\author{
CirCular 556
}

Geneva, 1 July 1991

\author{
To the Central Committees of the National \\ Red Cross and Red Crescent Societies
}

\section{LADIES AND GENTLEMEN,}

We have the honour to announce that the International Committee of the Red Cross, at its meeting of 1 May 1991, took formal note of the reunification of the German Red Cross.

The German Red Cross was officially reunified on 3 January 1991. In a letter dated 6 March 1991, the German government confirmed that the government recognition of 27 September 1956 remained valid and, in view of the country's reunification, now extended to the activities of the German Red Cross in the new federal Länder.

The first General Assembly of the reunified Society was held on 15 March 1991 to establish a new structure and elect new representatives. Botho Prince of Sayn-Wittgenstein is the President of the reunified Society, whose headquarters will be in Berlin although its secretariat will remain in Bonn at the following address: German Red Cross, Friedrich-Ebert-Allee 71, D-W-5300 Bonn 1.

New Statutes were drawn up and submitted to the Joint ICRC/League Commission on National Society Statutes in accordance with Resolution VI of the 22nd International Conference (Tehran 1973) and Resolution XX of the 24th International Conference (Manila 1981). The Commission has approved them.

The Yemen Red Crescent Society has informed the ICRC of the merger, on 18 July 1990, of the two former Yemeni Societies. At the new Society's first General Assembly, on 7 June 1991, Mr. Yehya Hussein Al-Arashi was 
elected its President. The Headquarters of the Society is in Sana'a, at the following address: Yemen Red Crescent Society, Head Office, Building No. 10, 26 September Street, Sana'a.

The unification of these two National Societies means that there are now 147 National Societies members of the International Red Cross and Red Crescent Movement.

The International Committee of the Red Cross wishes the German Red Cross and the Yemen Red Crescent Society every success in the continuation and development of their humanitarian activities.

FOR THE INTERNATIONAL COMMITTEE

OF THE RED CROSS

Cornelio Sommaruga

President

\section{Recognition of the Solomon Islands Red Cross Society}

The International Committee of the Red Cross has recognized the Solomon Islands Red Cross Society.

This recognition, which took effect on 3 October 1991, brings to 148 the number of National Societies which are members of the International Red Cross and Red Crescent Movement. 